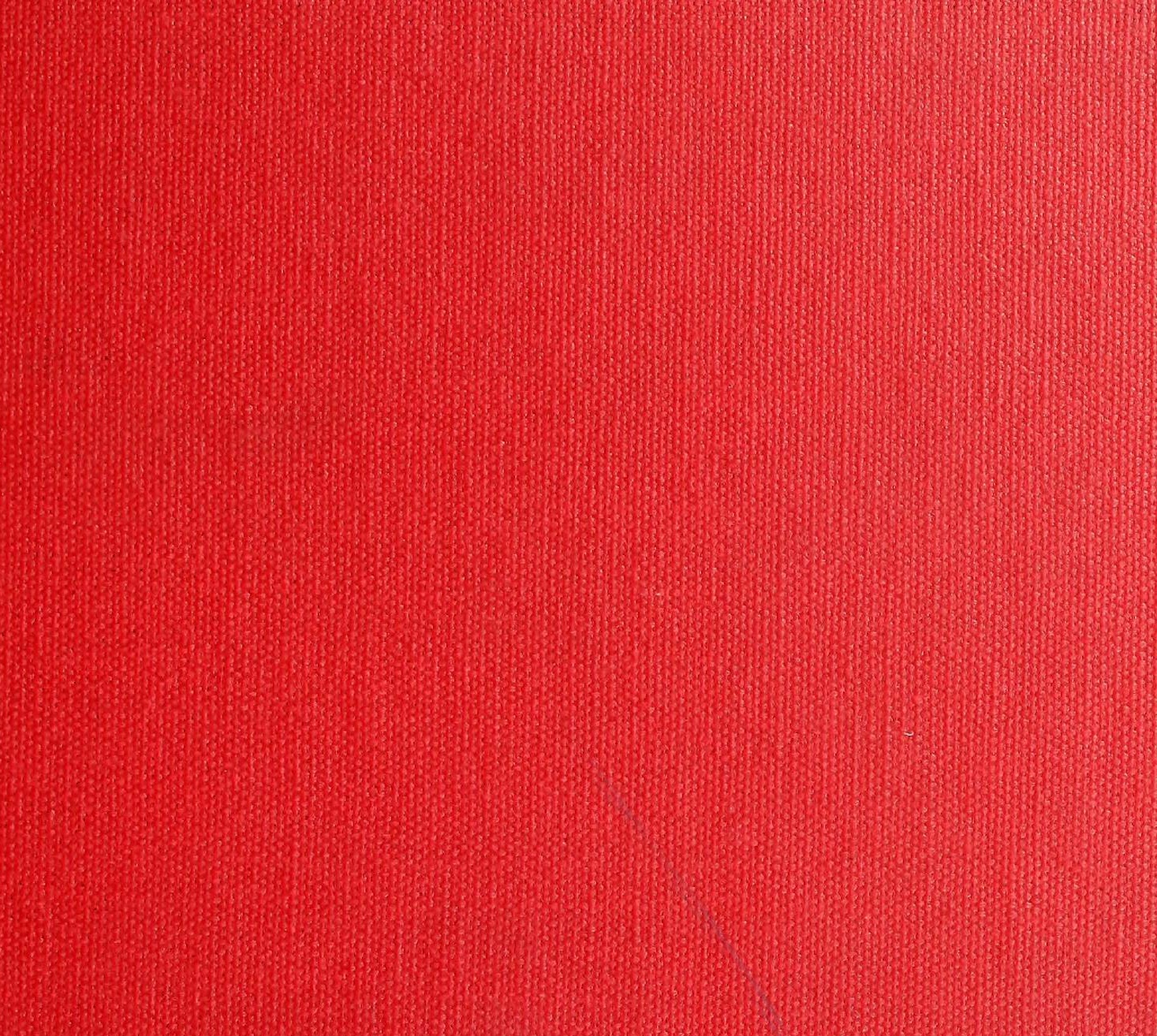

re 2. D.

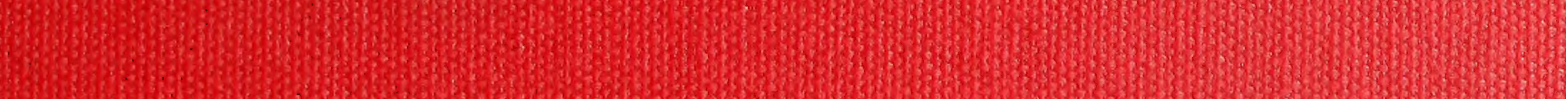
3. 6. H. 4. H. Q67. 1.7. B.8. 3. Whom

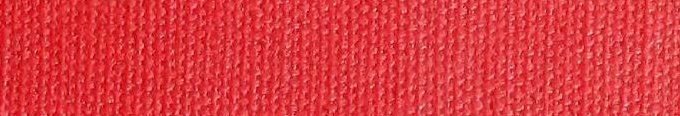
3.t. 3.

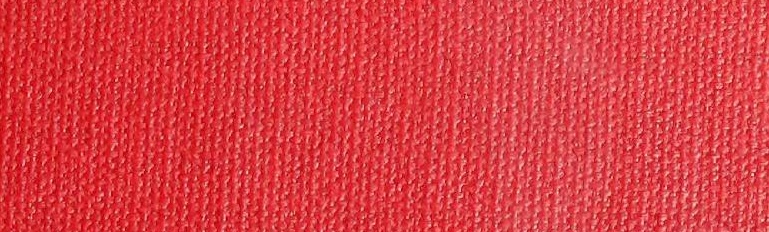




\section{Historic, archived document}

Do not assume content reflects current scientific knowledge, policies, or practices. 
1792

\section{INSECT DAMAGE TO CORN \\ IN THREE SOUTHEASTERN STATES \\ AT TIME OF HARVEST \\ AND IN FARM STORAGE}

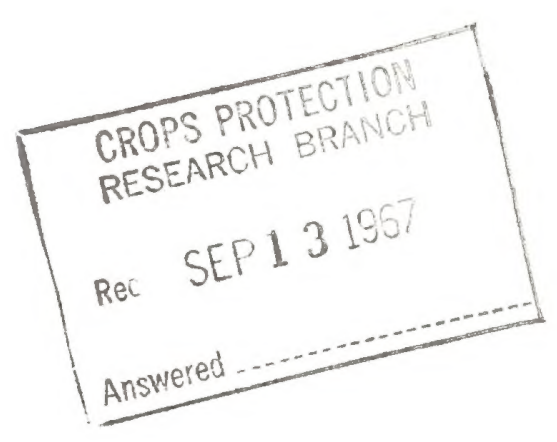

Agricultural Research Service

U.S. DEPARTMENT OF AGRICULTURE 


\section{CONTENTS}

Summary _.

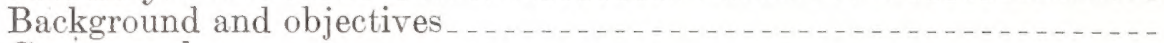

Corn samples.................

Species and abundance of insects . . . . . . .

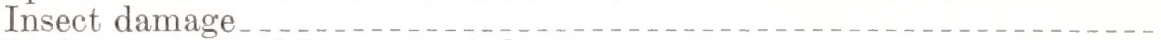

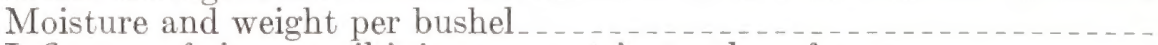

Influence of rice weevil injury on nutrient value of corn

Losses

This work was done under USDA contract No. 12-25-010-5317, dated September 11, 1962, with Auburn University Agricultural Experiment Station, Auburn, Ala.

Although the data on which this report is based were collected in 1962 and 1963, the findings are still valid and useful as guidelines for developing research needed to find ways to prevent losses from insect attack. 


\title{
INSECT DAMAGE TO CORN IN THREE SOUTHEASTERN STATES AT TIME OF HARVEST AND IN FARM STORAGE
}

\author{
By W. G. Eden ${ }^{1}$
}

\section{SUMMARY}

Samples of stored corn collected at harvest in Georgia, Alabama, and Mississippi, in October 1962 contained an average of about 19 insects per pint. By July 1963, the numbers had begun to increase, and by October they had multiplied eightfold to 151 insects per pint. The majority of these were the rice weevil. Of the 16 other species found, the most numerous was the red flour beetle. The flat grain beetle, the cadelle, and the squarenecked grain beetle, were present but not so numerous.

The corn was X-rayed to determine insect damage at each sampling period. The difference in degree of effectiveness of fumigation and protective treatments was slight, but both gave some protection to ear corn. Fumigation did protect shelled corn somewhat, but protectants were considerably more effective. The average weight per bushel for the samples decreased from 53.7 pounds to 45.8 pounds during the year.
As rice weevil infestation increased, the fat content did not change significantly but the carbohydrate content of the corn decreased, and the protein content increased. Weight per bushel of corn and quality (weight of nutrients) decreased significantly as rice weevil injury increased.

The loss in nutrients was the basis for estimating the dollar loss to the crop. At harvest, insects had already caused losses of $\$ 1,900,000$ in Georgia's 50 -million-bushel corn crop, $\$ 1,300,000$ in Alabama's 35 million bushels, and $\$ 760,000$ in Mississippi's nearly 21 million bushels. By the end of 1 year of storage on the farm these losses had been increased to $\$ 4,565,000$ in Georgia, $\$ 3,550,000$ in Alabama, and $\$ 1,850,000$ in Mississippi. Thus, during the year the loss from insect damage to farm-stored 1962-crop corn in the three Southeastern States had increased from about $\$ 4$ million to nearly $\$ 10$ million.

\section{BACKGROUND AND OBJECTIVES}

Insect damage to corn in the Southern States is perhaps the most serious grain-insect problem facing our country. Studies in Louisiana have shown that an average of 10 percent of the kernels of corn were infested at harvesttime. This damage increased to 17 percent after approximately 6 months of storage, and to more than 30 percent after 9 months. ${ }^{2}$ Inasmuch as insect damage to corn depends on several factors, including infestation at harvest, type of storage, and treatment, data were needed on how corn was stored and treated in these States.

A study was planned to cover the harvest and storage of 1 year's corn crop in three Southeastern States. One objective was to develop a reliable dollar value for the losses from insect attack. Data would be sought on the factors that influence or govern insect attack and damage to stored corn. From such a project, guidelines might be developed on phases of research needed to develop practical means for preventing such losses.

1 The author is an entomologist, formerly at Auburn University, Auburn, Ala., and now at the University of Florida, Gainesville.

${ }^{2}$ Floyd, E. H., Oliver, A. D., and Powell, Joe Don. DAMAGE TO CORN IN LOUISIANA CAUSED BY STORED-GRAIN INSECTS. Jour. Econ. Ent. 52(4) : 612-616. August 1959.
The study was conducted in Alabama, Georgia, and Mississippi, three large corn-producing States in the Southeast. ${ }^{3}$ Only farm-stored corn was considered.

The basic objectives of this study were (1) th determine the species, abundance, and relative importance of various stored-corn insects throughout the year in three Southeastern States; (2) to establish insofar as possible the actual monetary value of the damage caused by insects in stored corn; and (3) to determine the kinds and extent of insect control measures presently used and their effectiveness.

The entire project was carried out under contract with the Auburn University Agricultural Experiment Station. Experiment station personnel, county agricultural agents, and farmers in the three States cooperated in the work by locating - corn for the study and making initial contact. ${ }^{4}$

\footnotetext{
3 U.S. Department of Agriculture. Agricultural STATISTICS, 1965. 635 pp. 1965.

4 Dr. C. R. Jordan, Georgia; Roy J. Ledbetter, Alabama; and A. G. Bennett, Mississippi, extension entomologists in their respective States, cooperated in this study. Dr. A. E. Drake, formerly associate biometrician, and W. H. Hearn, systems analyst, Auburn University Agricultural Experiment Station, aided in the various statistical computations.
} 


\section{CORN SAMPLES}

To provide samples of corn for study, $62 \mathrm{co-}$ operating farmers were selected in Georgia, 60 in Alabama, and 66 in Mississippi. Samples of the 1962 corn crop were collected from each in October 1962, and January, April, July, and October of 1963. A summary of the types of stored corn and treatments sampled is presented in table 1. A sample of ear corn consisted of 100 ears. For shelled corn, probe samples taken at different locations in the bin were composited to make a single sample of at least $1 / 2$ bushel.

Of the 188 cooperators originally selected, one was discontinued before the first sample was collected in October; one was discontinued in January, seven in April, nine in July, and 19 in October. A total of 37 of the original 188 cooperators were unable to provide samples at the end of the period. Otherwise, the collection and processing of all samples was done as indicated.

Samples were processed in the laboratory at Auburn. Processing consisted of husking and shelling the ear corn, sampling the uncleaned corn for insects, cleaning, and determining the moisture content, weight per bushel, and insect damage. The insects were removed from the
TABle 1.-Distribution of 1962-crop corn samples in the study in 3 Southeastern States, by type of sample and storage treatment

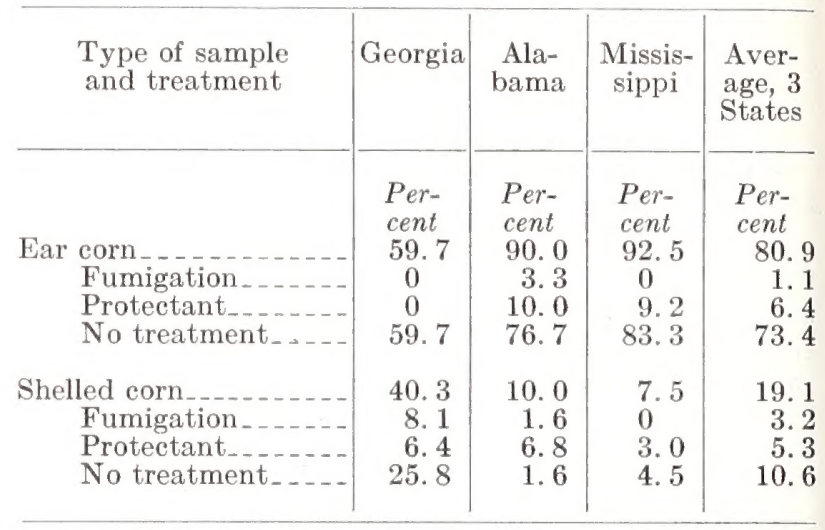

uncleaned subsample by screening and were counted and classified. Moisture content of cleaned samples was determined with a Steinlite moisture tester. Insect damage in cleaned samples was determined by X-ray pictures taken with a Westinghouse grain inspection X-ray unit. ${ }^{5}$

\section{SPECIES AND ABUNDANCE OF INSECTS}

The following insect species were found in stored corn in the three-State area:

(1) Angoumois grain moth, Sitotroga cerealella (Olivier)

(2) Broad-horned flour beetle, Gnathocerus cornutus (Fabricius)

(3) Cadelle, Tenebroides mauritanicus (Linnaeus)

(4) Cigarette beetle, Lasioderma serricorne (Fabricius)

(5) Confused flour bettle, Tribolium confusum Jacquelin duVal

(6) Corn sap beetle, Carpophilus dimidiatus (Fabricius)

(7) Drugstore beetle, Stegobium paniceum (Linnaeus)

(8) Flat grain beetle, Cryptoiestes pusillus (Schönherr)

(9) Hairy fungus beetle, ${ }^{6}$ Typhaea stercorea (Linnaeus)

(10) Indian-meal moth, Plodia interpunctella (Hübner)

(11) Lesser grain borer, Rhyzopertha dominica (Fabricius)

(12) Red flour beetle, Tribolium casteneum (Herbst)

(13) Rice weevil, Sitophilus oryzae (Linnaeus)
(14) Saw-toothed grain beetle, Oryzaephilus surin amensis (Linnaeus)

(15) Slender-horned flour beetle, ${ }^{6}$ Gnathocerus maxillosus (Fabricius)

(16) Square-necked grain beetle, Cathartus quadricollis (Guérin-Méneville)

(17) Yellow mealworm, Tenebrio molitor (Linnaeus) The average number of insects by species for all samples in each State and in the three-State area throughout the 1-year period are given in table 2 . There was an average of about 16 insects per pint of shelled corn from all samples (both shelled corn and ear corn that had been shelled) in Georgia and Alabama and 25 insects per pint in Mississippi when the corn was stored in the fall of 1962 . These numbers remained about constant, or actually dropped slightly, in samples collected in January and April. They began to increase in the July samples and had increased about eightfold by October.

5 Trade names are used in this publication solely to provide specific information. Mention of a trade name does not constitute a guarantee or warranty of the product by the U.S. Department of Agriculture and does not signify that the product is approved to the exclusion of other comparable products.

${ }^{6}$ Common name not approved by the Entomological Society of America. 
TABLE 2.-Number of each species of insect per pint sample of 1962-crop shelled corn, 3 Southeastern States, quarterly, 1962-63

\begin{tabular}{|c|c|c|c|c|c|}
\hline Species and State & $\begin{array}{l}\text { Oc- } \\
\text { tober } \\
1962\end{array}$ & $\begin{array}{l}\text { Jan- } \\
\text { uary } \\
1963\end{array}$ & $\begin{array}{c}\text { April } \\
1963\end{array}$ & $\begin{array}{l}\text { July } \\
1963\end{array}$ & $\begin{array}{l}\text { Oc- } \\
\text { tober } \\
1963\end{array}$ \\
\hline $\begin{array}{l}\text { Angoumois grain moth, average } \\
\text { Georgia } \\
\text { Alabama } \\
\text { Mississippi }\end{array}$ & $\begin{array}{c}\text { Number } \\
2.2 \\
2.5 \\
1.8 \\
2.3\end{array}$ & $\begin{array}{c}\text { Number } \\
1.5 \\
1.4 \\
1.6 \\
1.5\end{array}$ & $\begin{array}{c}\text { Number } \\
0.4 \\
.2 \\
.3 \\
.8\end{array}$ & $\begin{array}{r}\text { Number } \\
\text { 1. } 4 \\
\text { 1. } 4 \\
\text { 2. } 8\end{array}$ & $\begin{array}{r}\text { Number } \\
2.8 \\
1.3 \\
6.5\end{array}$ \\
\hline $\begin{array}{l}\text { Cadelle, average } \\
\text { Georgia } \\
\text { Alabama } \\
\text { Mississippi }\end{array}$ & $\begin{array}{l}0 \\
0 \\
0 \\
0\end{array}$ & $\begin{array}{l}.04 \\
07 \\
05\end{array}$ & $\begin{array}{l}.05 \\
.08 \\
.02 \\
.05\end{array}$ & $\begin{array}{l}\text { 2. } 1 \\
\text { 1. } 6 \\
\text { 2. } 6 \\
\text { 2. } 0\end{array}$ & $\begin{array}{l}\text { 5. } 0 \\
\text { 4. } 2 \\
\text { 4. } 0 \\
\text { 6. } 7\end{array}$ \\
\hline $\begin{array}{l}\text { Confused flour beetle, average } \\
\text { Georgia } \\
\text { Alabama } \\
\text { Mississippi }\end{array}$ & $\begin{array}{l}2 \\
.05 \\
\cdot 1 \\
3\end{array}$ & $\begin{array}{l}.2 \\
.05 \\
.2 \\
.2\end{array}$ & $\begin{array}{l}3 \\
2 \\
2 \\
4\end{array}$ & $\begin{array}{l}.5 \\
.4 \\
6 \\
.6\end{array}$ & $\begin{array}{l}\text { 2. } 2 \\
\text { 2. } 0 \\
\text { 2. } 3 \\
\text { 2. } 3\end{array}$ \\
\hline $\begin{array}{l}\text { Corn sap beetle, average } \\
\text { Georgia } \\
\text { Alabama } \\
\text { Mississippi }\end{array}$ & $\begin{array}{l}.1 \\
3 \\
.05 \\
.03\end{array}$ & $\begin{array}{l}.07 \\
.1 \\
.03 \\
.08\end{array}$ & $\begin{array}{l}.03 \\
.03 \\
0 \\
0\end{array}$ & $\begin{array}{l}0 \\
0 \\
0 \\
0\end{array}$ & $\begin{array}{l}\text { 3. } 2 \\
\text { 1. } 9 \\
\text { 5. } 2 \\
\text { 2. } 4\end{array}$ \\
\hline $\begin{array}{l}\text { Flat grain beetle, average } \\
\text { Georgia } \\
\text { Miabama } \\
\text { Mississippi }\end{array}$ & $\begin{array}{l}.1 \\
.05 \\
.05 \\
.3\end{array}$ & $\begin{array}{l}.2 \\
.08 \\
.07 \\
.5\end{array}$ & $\begin{array}{l}1 \\
.07 \\
.2 \\
.2\end{array}$ & $\begin{array}{l}0 \\
0 \\
0\end{array}$ & $\begin{array}{l}\text { 5. } 8 \\
\text { 6. } 6 \\
\text { 4. } 5 \\
\text { 6. } 2\end{array}$ \\
\hline $\begin{array}{l}\text { Indian-meal moth, average } \\
\text { Georgia } \\
\text { Alabama } \\
\text { Mississippi }\end{array}$ & $\begin{array}{l}0 \\
0 \\
0 \\
0\end{array}$ & $\begin{array}{l}0 \\
0 \\
0 \\
0\end{array}$ & $\begin{array}{l}\text { 1. } 3 \\
\text { 1. } 3 \\
\text { 1. } 6 \\
\text { 1. } 0\end{array}$ & $\begin{array}{r}.6 \\
.7 \\
.2 \\
\text { 1. } 0\end{array}$ & $\begin{array}{l}\text { 1. } 7 \\
\text { 1. } 4 \\
\text { 3. } 6 \\
\text { 3. } 1\end{array}$ \\
\hline $\begin{array}{l}\text { Red flour beetle, average } \\
\text { Georgia } \\
\text { Alabama } \\
\text { Mississippi }\end{array}$ & $\begin{array}{l}0.04 \\
.01 \\
.05 \\
.05\end{array}$ & $\begin{array}{l}0.2 \\
.1 \\
.08 \\
.3\end{array}$ & $\begin{array}{l}0.1 \\
.2 \\
.07 \\
.2\end{array}$ & $\begin{array}{l}2.9 \\
1.0 \\
5.5 \\
2.1\end{array}$ & $\begin{array}{r}11.4 \\
10.5 \\
9.0 \\
14.8\end{array}$ \\
\hline $\begin{array}{l}\text { Rice weevil, average } \\
\text { Georgia } \\
\text { Alabama } \\
\text { Mississippi }\end{array}$ & $\begin{array}{r}\text { 9. } 6 \\
\text { 7. } 4 \\
\text { 7. } 2 \\
\text { 14. } 3\end{array}$ & $\begin{array}{r}8.3 \\
6.9 \\
7.5 \\
10.5\end{array}$ & $\begin{array}{r}8.9 \\
10.3 \\
6.4 \\
10.0\end{array}$ & $\begin{array}{l}20.4 \\
16.8 \\
26.5 \\
17.9\end{array}$ & $\begin{array}{r}109.2 \\
52.3 \\
129.9 \\
145.3\end{array}$ \\
\hline $\begin{array}{l}\text { Saw-toothed grain beetle, average } \\
\text { Georgia } \\
\text { Alabama } \\
\text { Mississippi }\end{array}$ & $\begin{array}{l}0 \\
0 \\
0 \\
0\end{array}$ & $\begin{array}{l}.07 \\
.08 \\
.05 \\
.08\end{array}$ & $\begin{array}{l}.1 \\
.08 \\
.05 \\
.3\end{array}$ & $\begin{array}{r}.9 \\
.8 \\
.4 \\
1.4\end{array}$ & $\begin{array}{ll}\text { 2. } & 5 \\
\text { 2. } & 5 \\
\text { 3. } & 1 \\
\text { 1. } & 9\end{array}$ \\
\hline $\begin{array}{l}\text { Square-necked grain beetle, average } \\
\text { Georgia } \\
\text { Alabama } \\
\text { Mississippi }\end{array}$ & $\begin{array}{l}\text { 6. } 6 \\
5.5 \\
6.3 \\
\text { 7. } 9\end{array}$ & $\begin{array}{l}\text { 6. } 5 \\
9.8 \\
\text { 4. } 8 \\
\text { 4. } 8\end{array}$ & $\begin{array}{l}\text { 2. } 9 \\
2.7 \\
\text { 3. } 3 \\
\text { 2. } 6\end{array}$ & $\begin{array}{l}\text { 1. } 6 \\
1.2 \\
2.0 \\
1.5\end{array}$ & $\begin{array}{l}\text { 4. } 3 \\
\text { 3. } 7 \\
\text { 4. } 9 \\
\text { 4. } 4\end{array}$ \\
\hline $\begin{array}{l}\text { Yellow mealworm, average } \\
\text { Georgia } \\
\text { Alabama } \\
\text { Mississippi }\end{array}$ & $\begin{array}{l}0 \\
0 \\
0 \\
0\end{array}$ & $\begin{array}{l}0 \\
0 \\
0 \\
0\end{array}$ & $\begin{array}{l}0 \\
0 \\
0 \\
0\end{array}$ & $\begin{array}{l}0 \\
0 \\
0 \\
0\end{array}$ & $\begin{array}{l}4 \\
1 \\
4 \\
7\end{array}$ \\
\hline $\begin{array}{l}\text { Miscellaneous species, average }{ }^{1} \ldots \\
\text { Georgia } \\
\text { Alabama } \\
\text { Mississippi }\end{array}$ & $\begin{array}{l}.06 \\
.12 \\
.06 \\
.02\end{array}$ & $\begin{array}{l}.02 \\
.02 \\
.03 \\
.02\end{array}$ & $\begin{array}{l}0 \\
0 \\
0 \\
0\end{array}$ & $\begin{array}{l}\text { 1. } 2 \\
\text { 1. } 5 \\
\text { 1. } 2\end{array}$ & $\begin{array}{l}\text { 2. } 6 \\
\text { 2. } 1 \\
\text { 3. } 7 \\
\text { 2. } 0\end{array}$ \\
\hline $\begin{array}{l}\text { Total, all species, average } \\
\text { Georgia } \\
\text { Alabama } \\
\text { Mississippi }\end{array}$ & $\begin{array}{l}\text { 18. } 9 \\
15.9 \\
15.6 \\
25.2\end{array}$ & $\begin{array}{l}17.1 \\
18.6 \\
14.4 \\
18.0\end{array}$ & $\begin{array}{l}14.2 \\
15.2 \\
12.2 \\
15.6\end{array}$ & $\begin{array}{l}31.6 \\
23.7 \\
40.4 \\
30.5\end{array}$ & $\begin{array}{r}151.1 \\
88.6 \\
168.1 \\
196.5\end{array}$ \\
\hline
\end{tabular}

${ }^{1}$ Includes combined numbers of hairy fungus beetle, eigarette beetle, drugstore beetle, broad-horned flour beetle, slender-horned flour beetle, and lesser grain borer. 
The rice weevil was, by far, the most numerous species of insect in the stored corn in each of the States. In numbers it made up one-half or more of all insects collected in October 1962 and the following January and April. The proportion of rice weevils increased in the July samples, and by October 1963 the rice weevil constituted more than 70 percent of the 151.1 insects per pint of all samples. The average sample in Georgia con- tained 88.6, in Alabama 168.1, and in Mississippi 196.5 insects per pint.

By the end of the 1-year storage period, the second most numerous species in each State was the red flour beetle, which made up about 7.5 percent of the total. Of still lesser importance were the flat grain beetle, the cadelle, and the square-necked grain beetle. In Alabama the corn sap beetle and in Mississippi the Angoumois grain moth were also important.

\section{INSECT DAMAGE}

Insect damage throughout the year, as shown by X-ray examination of the samples for the threeState area, is given in table 3 . The averages for all samples show an initial 12.2 percent of the kernels damaged by insects. This increased gradually throughout the 1-year storage period to 38.1 percent. In Georgia this increase was from 11.6 to 32.7 percent, in Alabama from 10.7 to 38.2 percent, and in Mississippi from 14.2 to 43.4 percent.

Injury in the untreated ear corn increased from an initial percentage of 11.6 to 37.5 for the three States at the end of the year. In Georgia, the average gradually increased from 10.7 percent of the kernels when storage began to 26.3 percent at the end of the period. The injury in Alabama gradually increased from 10.1 percent to 40.3 percent. In Mississippi, the injury was 14.1 percent when storage began, and 45.8 percent at the end of the year.

Fumigated ear corn was sampled in Alabama only. It had 8.5 percent damage at the beginning and increased to 23.1 percent at the end of the storage period.

Ear corn treated with protectant in Alabama had 13.2 percent kernel injury at the beginning of storage, which increased to 35.3 percent. In Mississippi, ear corn treated with protectant started with 15.7 percent injury at the beginning of storage, but increased to only 18.2 percent at the end. No ear corn treated with protectant was sampled in Georgia.

Insect damage in untreated shelled corn for two of the States increased from an initial 13.6 percent damage to 51.9 percent in 1 year. In Georgia, 13.5 percent of the kernels were injured when storage began and this increased to 43.8 percent at the end of 1 year; in Mississippi the increase was from 14.9 percent to 60 percent. In Alabama, cooperators were unable to hold untreated shelled corn throughout the year, so no comparison of the treated with untreated shelled corn could be made.

In fumigated shelled corn the average kernel injury in all States increased from 13.2 percent to 40.4 percent. In Georgia, the injury in fumigated shelled corn increased from 12.6 percent average damage at the beginning to only 26.9 percent in July, compared to 39 in the untreated. By the end of the year, however, it was 41.5 percent, almost as much as in the untreated corn. The increase in Alabama was from 13.7 percent injury to 39.3 percent. None of the shelled corn sampled in Mississippi had been fumigated.

In shelled corn treated with protectants in all three States, the average increase in insect injury was from 12.9 percent of the kernels to 26.7 percent. In Georgia, the injury was 12.6 percent at the beginning of storage; it increased more slowly than in the untreated or fumigated corn and was 34.9 percent at the end of the year. In Alabama, injury increased from 13.8 percent initially to 30.1 percent at the end of the year: Shelled corn treated with protectants in Mississippi increased to only 15 percent kernel injury from an initial 12.3 percent.

Thus, while fumigation of shelled corn resulted in less insect injury than no treatment, the use of protectants was considerably more effective in all three States. In ear corn, protectants gave excellent control of insects in Mississippi. In Alabama, the only State in which fumigants and protectants could be compared for ear corn, fumigation resulted in better insect control than the use of protectants or no treatment.

There was greater injury during the year to untreated shelled corn than to untreated ear corn, both in Georgia and Mississippi. Injury in untreated ear corn increased in all States from 11.6 to 37.5 percent of the kernels in 1 year, but it increased from 13.6 to 51.9 in untreated shelled corn. 
TABLE 3.-Percentage of 1962-crop corn kernels damaged by insects in each type of sample and storage treatment, 3 Southeastern States, quarterly, 1962-63

\begin{tabular}{|c|c|c|c|c|c|}
\hline $\begin{array}{c}\text { State, type of sample, and storage } \\
\text { treatment }\end{array}$ & $\begin{array}{l}\text { October } \\
1962\end{array}$ & $\underset{1963}{\text { January }}$ & $\begin{array}{l}\text { April } \\
1963\end{array}$ & $\begin{array}{l}\text { July } \\
1963\end{array}$ & $\begin{array}{l}\text { October } \\
1963\end{array}$ \\
\hline $\begin{array}{l}\text { GEORGIA } \\
\text { All samples, average } \ldots . . .\end{array}$ & $\begin{array}{r}\text { Percent } \\
11.6\end{array}$ & $\begin{array}{r}\text { Percent } \\
13.5\end{array}$ & $\begin{array}{c}\text { Percent } \\
19.9\end{array}$ & $\begin{array}{r}\text { Percent } \\
25.5\end{array}$ & $\begin{array}{r}\text { Percent } \\
32.7\end{array}$ \\
\hline $\begin{array}{l}\text { Ear corn: } \\
\quad \text { No treatment }\end{array}$ & 10.7 & 12.7 & 16.7 & 20.7 & 26.3 \\
\hline $\begin{array}{l}\text { Shelled corn, average } \\
\text { Fumigation } \\
\text { Protectant } \\
\text { No treatment }\end{array}$ & $\begin{array}{l}12.9 \\
12.6 \\
12.6 \\
13.5\end{array}$ & $\begin{array}{l}14.3 \\
15.6 \\
12.1 \\
15.3\end{array}$ & $\begin{array}{l}23.8 \\
28.4 \\
17.8 \\
25.3\end{array}$ & $\begin{array}{l}29.0 \\
26.9 \\
21.1 \\
39.0\end{array}$ & $\begin{array}{l}40.1 \\
41.5 \\
34.9 \\
43.8\end{array}$ \\
\hline \multicolumn{6}{|l|}{ ALABAMA } \\
\hline All samples, average & 10. 7 & 14. 1 & 18. 1 & 25.4 & 38.2 \\
\hline $\begin{array}{l}\text { Ear corn, average } \\
\text { Fumigation } \\
\text { Protectant } \\
\text { No treatment }\end{array}$ & $\begin{array}{r}10.6 \\
8.5 \\
13.2 \\
10.1\end{array}$ & $\begin{array}{l}14.3 \\
15.1 \\
13.9 \\
14.0\end{array}$ & $\begin{array}{l}20.8 \\
27.6 \\
17.1 \\
17.8\end{array}$ & $\begin{array}{l}23.2 \\
25.2 \\
17.9 \\
26.4\end{array}$ & $\begin{array}{l}32.9 \\
23.1 \\
35.3 \\
40.3\end{array}$ \\
\hline $\begin{array}{l}\text { Shelled corn, average } \\
\text { Fumigation } \\
\text { Protectant } \\
\text { No treatment. }\end{array}$ & $\begin{array}{l}13.3 \\
13.7 \\
13.8 \\
12.5\end{array}$ & $\begin{array}{l}14.6 \\
14.8 \\
12.1 \\
17.0\end{array}$ & $\begin{array}{l}17.6 \\
16.2 \\
19.0\end{array}$ & $\begin{array}{l}23.6 \\
19.8 \\
27.3\end{array}$ & $\begin{array}{l}\text { 34. } 7 \\
39.3 \\
30.1\end{array}$ \\
\hline \multicolumn{6}{|l|}{ MISSISSIPPI } \\
\hline All samples, average & 14. 2 & 14. 4 & 19. 7 & 29.4 & 43. 4 \\
\hline $\begin{array}{l}\text { Ear corn, average } \ldots . . . \\
\text { Protectant } \\
\text { No treatment }\end{array}$ & $\begin{array}{l}\text { 14. } 9 \\
15.7 \\
14.1\end{array}$ & $\begin{array}{l}15.8 \\
17.9 \\
13.7\end{array}$ & $\begin{array}{l}22.5 \\
27.1 \\
17.9\end{array}$ & $\begin{array}{l}23.8 \\
17.7 \\
29.9\end{array}$ & $\begin{array}{l}32.0 \\
18.2 \\
45.8\end{array}$ \\
\hline $\begin{array}{l}\text { Shelled corn, average } \\
\text { Protectant } \\
\text { No treatment }\end{array}$ & $\begin{array}{l}13.6 \\
12.3 \\
14.9\end{array}$ & $\begin{array}{l}17.5 \\
12.8 \\
22.1\end{array}$ & $\begin{array}{l}29.1 \\
21.6 \\
36.5\end{array}$ & $\begin{array}{l}30.7 \\
13.4 \\
47.9\end{array}$ & $\begin{array}{l}37.5 \\
15.0 \\
60.0\end{array}$ \\
\hline \multicolumn{6}{|l|}{3 STATES } \\
\hline All samples, average & 12. 2 & 14.0 & 19. 2 & 26.8 & 38. 1 \\
\hline $\begin{array}{l}\text { Ear corn, average } \\
\text { Fumigation } \\
\text { Protectant } \\
\quad \text { No treatment }\end{array}$ & $\begin{array}{r}11.5 \\
8.5 \\
14.5 \\
11.6\end{array}$ & $\begin{array}{l}14.8 \\
15.1 \\
15.9 \\
13.5\end{array}$ & $\begin{array}{l}22.4 \\
27.6 \\
22.1 \\
17.5\end{array}$ & $\begin{array}{l}22.9 \\
25.2 \\
17.8 \\
25.7\end{array}$ & $\begin{array}{l}29.1 \\
23.1 \\
26.8 \\
37.5\end{array}$ \\
\hline $\begin{array}{l}\text { Shelled corn, average } \\
\text { Fumigation } \\
\text { Protectant } \\
\text { No treatment }\end{array}$ & $\begin{array}{l}\text { 13. } 2 \\
13.2 \\
12.9 \\
13.6\end{array}$ & $\begin{array}{l}15.2 \\
15.2 \\
12.3 \\
18.1\end{array}$ & $\begin{array}{l}24.2 \\
22.3 \\
19.5 \\
30.9\end{array}$ & $\begin{array}{l}29.2 \\
23.4 \\
20.6 \\
43.5\end{array}$ & $\begin{array}{l}39.7 \\
40.4 \\
26.7 \\
51.9\end{array}$ \\
\hline
\end{tabular}

\section{MOISTURE AND WEIGHT PER BUSHEL}

Moisture content and weight per bushel of the corn samples varied little between one State and another (table 4 ).

Moisture content for all samples in the three States decreased from 13.2 percent when storage began to 11.1 at the end of 1 year. Although the moisture content of the shelled samples was slightly lower than that of ear corn in the beginning of the study, the two were essentially the same at the end of a year of storage. Treatment with protectants or fumigants appeared to have little effect on moisture content of the corn.

The average weight per bushel of all samples was 53.7 pounds initially, and it gradually reduced to 45.8 pounds at the end of the period. The average weights per bushel of corn seemed to vary little between ear corn and shelled or between treated and untreated corn. 
TABLE 4.- Moisture content and weight per bushel of 1962-crop corn, by type of sample and storage treatment, 3 Southeastern States, quarterly, 1962-63

\begin{tabular}{|c|c|c|c|c|c|c|c|c|c|c|}
\hline \multirow{2}{*}{$\begin{array}{l}\text { State, type of sample, and } \\
\text { storage treatment }\end{array}$} & \multicolumn{2}{|c|}{ October 1962} & \multicolumn{2}{|c|}{ January 1963} & \multicolumn{2}{|c|}{ April 1963} & \multicolumn{2}{|c|}{ July 1963} & \multicolumn{2}{|c|}{ October 1963} \\
\hline & $\begin{array}{l}\text { Mois- } \\
\text { ture }\end{array}$ & Weight & $\begin{array}{l}\text { Mois- } \\
\text { ture }\end{array}$ & Weight & $\begin{array}{l}\text { Mois- } \\
\text { ture }\end{array}$ & Weight & $\begin{array}{l}\text { Mois- } \\
\text { ture }\end{array}$ & Weight & $\begin{array}{l}\text { Mois- } \\
\text { ture }\end{array}$ & Weight \\
\hline $\begin{array}{l}\text { GEORGI. } \\
\text { All samples, average... }\end{array}$ & $\begin{array}{l}\text { Percent } \\
13.2\end{array}$ & $\begin{array}{l}\text { Pounds } \\
54.0\end{array}$ & \begin{tabular}{|c|} 
Percent \\
13.8
\end{tabular} & $\begin{array}{c}\text { Pounds } \\
52.1\end{array}$ & $\begin{array}{l}\text { Percent } \\
11.8\end{array}$ & $\begin{array}{l}\text { Pounds } \\
51.7\end{array}$ & $\begin{array}{c}\text { Percent } \\
11.5\end{array}$ & $\left|\begin{array}{c}\text { Pounds } \\
50.0\end{array}\right|$ & $\begin{array}{c}\text { Percent } \\
11.3\end{array}$ & $\begin{array}{r}\text { Pounds } \\
46.5\end{array}$ \\
\hline $\begin{array}{l}\text { Ear corn: } \\
\quad \text { No treatment. }\end{array}$ & 13.5 & 53.9 & 14.0 & 51.7 & 12.0 & 51.4 & 11.6 & 50.4 & 10.9 & 47.2 \\
\hline $\begin{array}{l}\text { Shelled corn, average } \\
\text { Fumigation } \\
\text { Protectant } \\
\text { No treatment.- }\end{array}$ & $\begin{array}{l}12.7 \\
12.6 \\
12.8 \\
12.8\end{array}$ & $\begin{array}{l}54.3 \\
54.6 \\
54.2 \\
54.0\end{array}$ & $\begin{array}{l}13.5 \\
13.7 \\
13.3 \\
13.6\end{array}$ & $\begin{array}{l}53.1 \\
52.8 \\
54.2 \\
52.3\end{array}$ & $\begin{array}{l}11.7 \\
12.1 \\
11.6 \\
11.3\end{array}$ & $\begin{array}{l}52.6 \\
53.2 \\
52.9 \\
51.8\end{array}$ & $\begin{array}{l}11.3 \\
11.2 \\
11.7 \\
11.1\end{array}$ & $\begin{array}{l}50.2 \\
50.5 \\
51.8 \\
48.2\end{array}$ & $\begin{array}{l}11.6 \\
11.3 \\
11.2 \\
12.2\end{array}$ & $\begin{array}{l}46.3 \\
46.0 \\
48.2 \\
44.7\end{array}$ \\
\hline \multicolumn{11}{|l|}{$\triangle \mathrm{L} A \mathrm{~B} . \mathrm{MA}$} \\
\hline All samples, average & 13.2 & 53.8 & 13.9 & 52.1 & 12.3 & 51.3 & 11.1 & 50.3 & 11.1 & 46. 0 \\
\hline $\begin{array}{r}\text { Ear corn, average } . . . \\
\text { Fumigation } \ldots \\
\text { Protectant_... } \\
\text { No treatment.- }\end{array}$ & $\begin{array}{l}13.5 \\
14.3 \\
12.8 \\
13.3\end{array}$ & $\begin{array}{l}53.8 \\
54.2 \\
53.6 \\
53.7\end{array}$ & $\begin{array}{l}13.9 \\
14.4 \\
13.4 \\
14.0\end{array}$ & $\begin{array}{l}52.4 \\
53.1 \\
52.2 \\
52.0\end{array}$ & $\begin{array}{l}12.4 \\
12.9 \\
12.1 \\
12.2\end{array}$ & $\begin{array}{l}51.5 \\
51.5 \\
51.7 \\
51.2\end{array}$ & $\begin{array}{l}11.1 \\
11.1 \\
11.3 \\
11.0\end{array}$ & $\begin{array}{l}50.3 \\
50.0 \\
50.8 \\
50.2\end{array}$ & $\begin{array}{l}11.3 \\
11.7 \\
11.1 \\
11.1\end{array}$ & $\begin{array}{l}45.3 \\
42.7 \\
47.3 \\
45.9\end{array}$ \\
\hline $\begin{array}{l}\text { Shelled corn, average } \\
\text { Fumigation } \\
\text { Protectant } \\
\text { No treatment. }\end{array}$ & $\begin{array}{l}12.8 \\
13.4 \\
12.2 \\
12.7\end{array}$ & $\begin{array}{l}54.5 \\
56.4 \\
53.8 \\
53.4\end{array}$ & \begin{tabular}{l|l}
13.4 \\
14.6 \\
13.3 \\
12.2
\end{tabular} & $\begin{array}{l}52.6 \\
54.5 \\
52.5 \\
50.7\end{array}$ & $\begin{array}{l}12.9 \\
12.9 \\
12.8\end{array}$ & $\begin{array}{l}52.1 \\
52.2 \\
51.9\end{array}$ & $\begin{array}{l}11.6 \\
12.0 \\
11.2\end{array}$ & $\begin{array}{l}51.4 \\
52.0 \\
50.8\end{array}$ & $\begin{array}{l}11.1 \\
11.0 \\
11.1\end{array}$ & $\begin{array}{l}47.5 \\
49.1 \\
45.9\end{array}$ \\
\hline \multicolumn{11}{|l|}{ MISSISSIPPI } \\
\hline All samples, aver & 13.1 & 53.4 & 13.9 & 51.5 & 12.1 & 51.2 & 11.1 & 49.8 & 10.8 & 45.0 \\
\hline $\begin{array}{l}\text { Ear corn, average } \\
\text { Protectant } \\
\text { No treatment }\end{array}$ & $\begin{array}{l}12.7 \\
12.2 \\
13.2\end{array}$ & $\begin{array}{l}52.4 \\
51.0 \\
53.7\end{array}$ & $\begin{array}{l}13.7 \\
13.4 \\
14.5\end{array}$ & $\begin{array}{l}50.4 \\
48.9 \\
51.8\end{array}$ & $\begin{array}{l}12.0 \\
11.8 \\
12.2\end{array}$ & $\begin{array}{l}50.2 \\
48.9 \\
51.5\end{array}$ & $\begin{array}{l}11.0 \\
10.9 \\
11.1\end{array}$ & $\begin{array}{l}50.1 \\
50.4 \\
49.8\end{array}$ & $\begin{array}{l}10.8 \\
10.8 \\
10.8\end{array}$ & $\begin{array}{l}46.3 \\
48.2 \\
44.4\end{array}$ \\
\hline $\begin{array}{l}\text { Shelled corn, average. } \\
\text { Protectant_... } \\
\text { No treatment... }\end{array}$ & $\begin{array}{l}12.5 \\
12.0 \\
12.9\end{array}$ & $\begin{array}{l}53.3 \\
52.6 \\
53.9\end{array}$ & $\begin{array}{l}14.2 \\
13.9 \\
14.4\end{array}$ & $\begin{array}{l}51.5 \\
51.8 \\
51.1\end{array}$ & $\begin{array}{l}12.1 \\
11.9 \\
12.2\end{array}$ & $\begin{array}{l}50.6 \\
50.7 \\
50.5\end{array}$ & $\begin{array}{l}10.7 \\
10.6 \\
10.8\end{array}$ & $\begin{array}{l}49.8 \\
50.2 \\
49.4\end{array}$ & $\begin{array}{l}10.8 \\
11.0 \\
10.5\end{array}$ & $\begin{array}{l}48.2 \\
49.4 \\
47.0\end{array}$ \\
\hline \multicolumn{11}{|l|}{3 STATES } \\
\hline All samples, average & 13.2 & 53.7 & 13.9 & 51.9 & 12.1 & 51.4 & 11.2 & 50.0 & 11.1 & 45.8 \\
\hline $\begin{array}{c}\text { Ear corn, average } . . \\
\text { Fumigation... } \\
\text { Protectant } \\
\text { No treatment_- }\end{array}$ & $\begin{array}{l}13.4 \\
14.3 \\
12.5 \\
13.3\end{array}$ & $\begin{array}{l}53.4 \\
54.2 \\
52.3 \\
53.8\end{array}$ & $\begin{array}{l}13.9 \\
14.4 \\
13.4 \\
14.0\end{array}$ & $\begin{array}{l}51.7 \\
53.1 \\
50.1 \\
51.8\end{array}$ & $\begin{array}{l}12.4 \\
12.9 \\
12.0 \\
12.2\end{array}$ & $\begin{array}{l}51.1 \\
51.5 \\
50.3 \\
51.4\end{array}$ & $\begin{array}{l}11.1 \\
11.1 \\
11.1 \\
11.2\end{array}$ & $\begin{array}{l}50.2 \\
50.0 \\
50.6 \\
50.1\end{array}$ & $\begin{array}{l}11.2 \\
11.7 \\
11.0 \\
10.9\end{array}$ & $\begin{array}{l}45.4 \\
42.7 \\
47.8 \\
45.8\end{array}$ \\
\hline $\begin{array}{l}\text { 1elled corn, average } \\
\text { Fumigation } \\
\text { Protectant } \\
\text { No treatment }\end{array}$ & $\begin{array}{l}12.7 \\
13.0 \\
12.3 \\
12.8\end{array}$ & $\begin{array}{l}52.6 \\
50.5 \\
53.5 \\
53.8\end{array}$ & $\begin{array}{l}13.7 \\
14.2 \\
13.5 \\
13.4\end{array}$ & $\begin{array}{l}52.6 \\
53.7 \\
52.8 \\
51.4\end{array}$ & $\begin{array}{l}12.1 \\
12.5 \\
12.1 \\
11.8\end{array}$ & $\begin{array}{l}51.9 \\
52.7 \\
51.8 \\
51.2\end{array}$ & $\begin{array}{l}11.3 \\
11.6 \\
11.2 \\
11.0\end{array}$ & $\begin{array}{l}50.3 \\
51.3 \\
50.9 \\
48.8\end{array}$ & $\begin{array}{l}11.2 \\
11.2 \\
11.1 \\
11.4\end{array}$ & $\begin{array}{l}46.6 \\
46.0 \\
47.8 \\
45.9\end{array}$ \\
\hline
\end{tabular}




\section{INFLUENCE OF RICE WEEVIL INJURY ON NUTRIENT VALUE OF CORN}

The effect of infestation by rice weevils on the nutrient value of corn was estimated from data on the content of the carbohydrates, proteins, and fats remaining in the kernels. At this stage there were no samples that had no insect damage to the kernels, and since it was not possible to set up these samples so that a given percentage of kernel damage would result from the weevil infestations, regression equations were worked out on the basis of the data available. From these equations, the probable average percentages of each type of nutrient and the total nutrient content of the corn were worked out for various gradations of weevil damage to the corn. Regression equations were also used to estimate the probable weight of the corn per bushel at the given percentage of weevil damage and the pounds per bushel that consisted of nutrients. From the predicted weight of nutrients per bushel, the percentage of loss in nutrient value was calculated. These figures are shown in table 5.

The predicted carbohydrate content of the corn decreased as the weevil infestation increased. The decrease was from more than an estimated 76 percent carbohydrate content at 10 percent kernel infestation to less than 70.9 percent at 100 percent infestation. The protein content increased very slightly as rice weevil infestation increased. Although the change was not large (less than 2 percent between 10 and 100 percent infestation), the original data showed a definite and steady increase. The changes in fat content shown in table 5 were predicted from a cubic regression equation, which was the best fitting equation, but even this equation was not significant statistically. From the limited data available, it was not possible to determine whether weevil infestation exerted any consistent influence on fat content.

The predicted total percent of nutrients tended to increase as infestation rose to 40 percent. Above 40 percent infestation, the percent of total nutrients dropped markedly.

As weevil infestation increased, the weight per bushel of corn decreased At 10 percent infestation, the weight per bushel was more than 54 pounds, and it was less than 43 pounds at 100 percent infestation.

The nutritive value of corn was reduced considerably as rice weevil infestation increased. At 10 percent weevil infestation, the total nutrients weighed more than 49 pounds per bushel, but weighed less than 37 pounds at 100 percent infestation.

TABLE 5.-Estimates of effect of rice weevil infestation on weight and nutrient content of corn ${ }^{1}$

\begin{tabular}{|c|c|c|c|c|c|c|c|}
\hline \multirow{2}{*}{$\begin{array}{c}\text { Kernels damaged } \\
\text { by weevils (percent) }\end{array}$} & \multirow{2}{*}{$\begin{array}{l}\text { Weight } \\
\text { of corn }{ }^{2}\end{array}$} & \multicolumn{5}{|c|}{ Nutrient content of corn } & \multirow{2}{*}{$\begin{array}{l}\text { Loss in } \\
\text { total } \\
\text { nutrient } \\
\text { value of } \\
\text { corn }\end{array}$} \\
\hline & & Carbo- & Dr. & & To & & \\
\hline 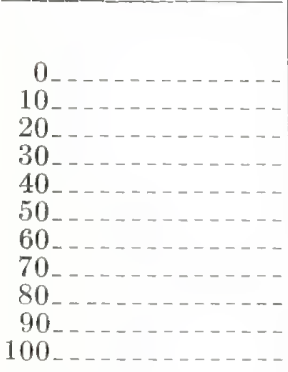 & $\begin{array}{r}\text { Pounds/ } \\
\text { bushel } \\
55.8 \\
54.4 \\
53.1 \\
51.8 \\
50.5 \\
49.1 \\
47.8 \\
46.5 \\
45.2 \\
43.8 \\
42.5\end{array}$ & $\begin{array}{l}\text { Percent } \\
76.8 \\
76.2 \\
75.6 \\
75.0 \\
74.4 \\
73.8 \\
73.2 \\
72.6 \\
72.1 \\
71.5 \\
70.9\end{array}$ & $\begin{array}{r}\text { Percent } \\
9.4 \\
9.6 \\
9.8 \\
\text { 10. } 0 \\
10.1 \\
10.3 \\
10.5 \\
10.7 \\
10.8 \\
11.0 \\
11.2\end{array}$ & $\begin{array}{r}\text { Percent } \\
\text { 5. } 8 \\
\text { 5. } 0 \\
\text { 4. } 7 \\
\text { 4. } 6 \\
\text { 4. } 8 \\
\text { 5. } 1 \\
\text { 5. } 4 \\
\text { 5. } 5 \\
\text { 5. } 3 \\
\text { 4. } 7 \\
\text { 3. } 5\end{array}$ & $\begin{array}{r}\text { Percent } \\
87.2 \\
88.7 \\
89.8 \\
90.5 \\
90.7 \\
90.6 \\
90.1 \\
89.1 \\
87.8 \\
86.0 \\
83.9\end{array}$ & $\begin{array}{r}\text { Pounds/ } \\
\text { bushel } \\
50.7 \\
49.3 \\
47.9 \\
46.5 \\
45.2 \\
43.8 \\
42.4 \\
41.0 \\
39.7 \\
38.3 \\
36.9\end{array}$ & $\begin{array}{r}\text { Percent } \\
0 \\
2.7 \\
5.4 \\
8.2 \\
10.9 \\
13.6 \\
16.3 \\
19.1 \\
21.8 \\
24.5 \\
27.2\end{array}$ \\
\hline
\end{tabular}

1 Derived from best-fitting regression equations.

2 These figures are calculated by formulas from original data, not from other columns of this table. 


\section{LOSSES}

Dollar losses to the 1962 corn crop from storedgrain pests were calculated for each State at the time the corn was stored and quarterly for the following year. The loss in weight of nutrients per bushel was used as the basis for calculating losses. The corn stocks on hand by quarters (table 6) were used in the estimates. The average percent of damaged kernels (table 3 ) in each type of storage and treatment on each date for the three States were converted to percent losses. The percent losses were applied to the bushels of corn in each type of storage and treatment at the end of the quarter. The average price received by farmers (table 7 ) was applied to the calculated bushel loss to give dollar loss (table 8). Losses of ear corn fumigated and treated with protectants in Georgia and fumigated ear and shelled corn in Mississippi were calculated from percentages of the crop estimated by county agents to have been so treated.

TABLE 6.-Production and quarterly stocks of 1962 corn crop, 3 Southeastern States, 1962-63 ${ }^{1}$

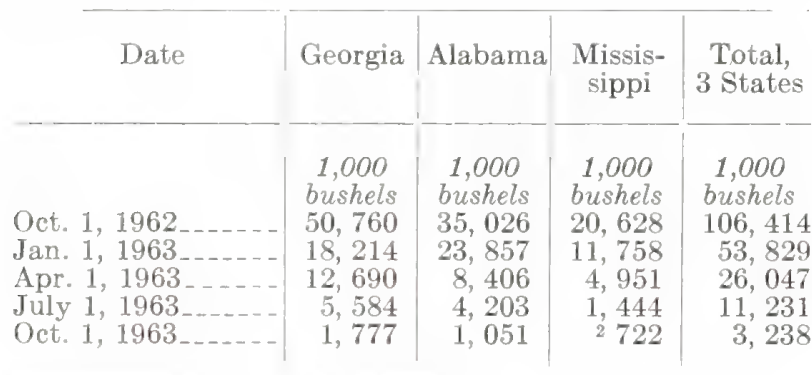

1 Statistical Reporting Service, U.S. Department of Agriculture.

${ }_{2}$ This figure was not available from the Statistical Reporting Service. The average percent of reduction in corn stocks in Georgia and Alabama between July and October was applied to the July figure in Mississippi.
TABLE 7.-Average price per bushel received by farmers for corn, 3 Southeastern States, quarterly, $1962-63^{1}$

\begin{tabular}{|c|c|c|c|c|}
\hline Date & Georgia & Alabama & $\begin{array}{l}\text { Missis- } \\
\text { sippi }\end{array}$ & $\begin{array}{l}\text { Average, } \\
3 \text { States }\end{array}$ \\
\hline $\begin{array}{l}\text { Nov. } 15,1962 \ldots \\
\text { Feb. 15, } 1963 \ldots \\
\text { May 15, } 1963 \ldots \\
\text { Aug. } 15,1963 \ldots\end{array}$ & $\begin{array}{r}\text { Dollars } \\
\text { 1. } 26 \\
\text { 1. } 38 \\
\text { 1. } 41 \\
1.41\end{array}$ & $\begin{array}{r}\text { Dollars } \\
1.20 \\
1.31 \\
1.36 \\
1.36\end{array}$ & $\begin{array}{r}\text { Dollars } \\
1.18 \\
1.35 \\
1.35 \\
1.40\end{array}$ & $\begin{array}{r}\text { Dollars } \\
\text { 1. } 21 \\
1.35 \\
1.37 \\
1.39\end{array}$ \\
\hline
\end{tabular}

${ }^{1}$ Statistical Reporting Service, U.S. Department of Agriculture.

There had been a loss of nearly $\$ 4$ million caused by stored-grain pests in the three States at the time the crop went into storage, and this damage increased as the storage period lengthened. By the end of the storage year the loss amounted to nearly $\$ 10$ million.

In the Georgia corn crop of more than 50 million bushels, damage from stored-grain insects increased from nearly $\$ 2$ million when the corn went into storage to $\$ 4 \frac{1}{2}$ million by the end of the year.

The loss of $\$ 1.3$ million to the 35-millionbushel Alabama corn crop when it was put into storage had become $\$ 3 \frac{1}{2}$ million by the end of the year.

The corn crop was short in Mississippi in 1962; production was only 20.6 million bushels. However, more than three-quarters of a million dollars was lost to stored-grain pests before the crop was stored. Nearly $\$ 2$ million had been lost by the end of the year of storage. 
TABLE 8.-Dollar value of losses caused by stored-grain insects to 1962-crop corn at harvest and during storage on farm, by type of sample and storage treatment, 3 Southeastern States, quarterly, 1962-63

\begin{tabular}{|c|c|c|c|c|c|c|}
\hline $\begin{array}{l}\text { State, type of sample, and } \\
\text { storage treatment }\end{array}$ & $\begin{array}{l}\text { Previous } \\
\text { to storage }\end{array}$ & $\begin{array}{l}\text { October to } \\
\text { December, } \\
\quad 1962\end{array}$ & $\begin{array}{l}\text { January to } \\
\text { March, } 1963\end{array}$ & $\begin{array}{l}\text { April to } \\
\text { June, } 1963\end{array}$ & $\begin{array}{l}\text { July to } \\
\text { September, } \\
1963\end{array}$ & Total \\
\hline $\begin{array}{c}\text { GEORGIA } \\
\text { All samples, all treatments_........ }\end{array}$ & $\begin{array}{l}1,000 \\
\text { dollars } \\
1,916.8\end{array}$ & $\begin{array}{l}\text { 1,000 } \\
\text { dollars } \\
\quad 885.8\end{array}$ & $\begin{array}{l}1,000 \\
\text { dollars } \\
953.5\end{array}$ & $\begin{array}{l}1,000 \\
\text { dollars } \\
562,4\end{array}$ & $\begin{array}{l}1,000 \\
\text { dollars } \\
247.1\end{array}$ & $\begin{array}{l}1,000 \\
\text { dollars } \\
4,565.7\end{array}$ \\
\hline $\begin{array}{l}\text { Ear corn, all treatments } \\
\text { Fumigation } \\
\text { Protectant } \\
\text { No treatment }\end{array}$ & $\begin{array}{r}1,646.5 \\
145.7 \\
163.2 \\
1,337.6\end{array}$ & $\begin{array}{r}759.8 \\
97.8 \\
67.3 \\
594.6\end{array}$ & $\begin{array}{r}795.3 \\
136.4 \\
71.6 \\
587.3\end{array}$ & $\begin{array}{r}469.9 \\
56.0 \\
25.9 \\
388.0\end{array}$ & $\begin{array}{r}209.2 \\
16.4 \\
12.4 \\
180.3\end{array}$ & $\begin{array}{r}3,880.6 \\
452.4 \\
340.4 \\
3,087.8\end{array}$ \\
\hline $\begin{array}{l}\text { Shelled corn, all treatments } \\
\text { Fumigation } \\
\text { Protectant } \\
\text { No treatment }\end{array}$ & $\begin{array}{r}270.3 \\
67.6 \\
34.1 \\
168.6\end{array}$ & $\begin{array}{r}126.1 \\
29.3 \\
12.2 \\
84.5\end{array}$ & $\begin{array}{r}158.2 \\
32.9 \\
14.8 \\
110.5\end{array}$ & $\begin{array}{r}92.5 \\
15.5 \\
7.0 \\
70.0\end{array}$ & $\begin{array}{r}38.0 \\
8.6 \\
3.0 \\
26.5\end{array}$ & $\begin{array}{r}685.0 \\
153.7 \\
71.2 \\
460.0\end{array}$ \\
\hline \multicolumn{7}{|l|}{ ALABAMA } \\
\hline All samples, all treatments $\ldots . . . . .$. & $1,301.0$ & $1,105.1$ & 599.6 & 408.2 & 141.0 & $3,554.9$ \\
\hline $\begin{array}{l}\text { Ear corn, all treatments } \\
\text { Fumigation } \\
\text { Protectant } \\
\text { No treatment }\end{array}$ & $\begin{array}{r}1,119.2 \\
98.0 \\
109.8 \\
911.3\end{array}$ & $\begin{array}{r}947.7 \\
122.1 \\
83.9 \\
741.8\end{array}$ & $\begin{array}{r}500.0 \\
85.8 \\
45.0 \\
369.2\end{array}$ & $\begin{array}{r}341.1 \\
40.7 \\
18.8 \\
281.7\end{array}$ & $\begin{array}{r}119.4 \\
9.3 \\
7.1 \\
102.9\end{array}$ & $\begin{array}{r}3,027.4 \\
355.8 \\
264.6 \\
2,406.9\end{array}$ \\
\hline $\begin{array}{l}\text { Shelled corn, all treatments } \\
\text { Fumigation } \\
\text { Protectant } \\
\text { No treatment } \\
\text { MIssissiPPI }\end{array}$ & $\begin{array}{r}181.8 \\
45.5 \\
22.9 \\
113.4\end{array}$ & $\begin{array}{r}157.4 \\
36.7 \\
15.3 \\
105.4\end{array}$ & $\begin{array}{r}99.5 \\
20.7 \\
9.3 \\
69.5\end{array}$ & $\begin{array}{r}67.2 \\
11.3 \\
5.1 \\
50.7\end{array}$ & $\begin{array}{r}21.6 \\
4.8 \\
1.7 \\
15.2\end{array}$ & $\begin{array}{r}527.5 \\
119.0 \\
54.3 \\
354.2\end{array}$ \\
\hline All samples, all treatments.......... & 759.7 & 535.6 & 363.9 & 139.2 & 56.7 & $1,855.0$ \\
\hline $\begin{array}{l}\text { Ear corn, all treatments } \\
\text { Fumigation } \\
\text { Protectant } \\
\text { No treatment }\end{array}$ & $\begin{array}{r}653.5 \\
57.2 \\
64.1 \\
532.1\end{array}$ & $\begin{array}{r}459.3 \\
59.2 \\
40.7 \\
359.5\end{array}$ & $\begin{array}{r}303.5 \\
52.1 \\
27.3 \\
224.1\end{array}$ & $\begin{array}{r}116.4 \\
13.9 \\
6.4 \\
96.1\end{array}$ & $\begin{array}{r}47.9 \\
3.8 \\
2.9 \\
41.3\end{array}$ & $\begin{array}{r}1,580.6 \\
186.1 \\
141.4 \\
1,253.1\end{array}$ \\
\hline $\begin{array}{l}\text { Shelled corn, all treatments } \\
\text { Fumigation } \\
\text { Protectant } \\
\text { No treatment }\end{array}$ & $\begin{array}{r}106.2 \\
26.6 \\
13.4 \\
66.2\end{array}$ & $\begin{array}{r}76.2 \\
17.7 \\
7.4 \\
51.1\end{array}$ & $\begin{array}{r}60.4 \\
12.6 \\
5.6 \\
42.1\end{array}$ & $\begin{array}{r}22.9 \\
3.9 \\
1.7 \\
17.3\end{array}$ & $\begin{array}{r}8.8 \\
2.0 \\
.6 \\
6.1\end{array}$ & $\begin{array}{r}274.4 \\
62.7 \\
28.8 \\
182.8\end{array}$ \\
\hline 3 STATES & & & & & & \\
\hline All samples, all treatments... & 3977.5 & $2,526.5$ & $1,916.9$ & $1,109.8$ & 444.8 & $9,975.5$ \\
\hline $\begin{array}{l}\text { Ear corn, all treatments } \\
\text { Fumigation } \\
\text { Protectant } \\
\text { No treatment }\end{array}$ & $\begin{array}{r}3,419.2 \\
301.0 \\
337.1 \\
2,781.1\end{array}$ & $\begin{array}{r}2,166.8 \\
279.1 \\
191.9 \\
1,695.9\end{array}$ & $\begin{array}{r}1,598.8 \\
274.3 \\
143.9 \\
1,180.6\end{array}$ & $\begin{array}{r}927.3 \\
110.5 \\
51.0 \\
765.7\end{array}$ & $\begin{array}{r}376.4 \\
29.5 \\
22.4 \\
324.5\end{array}$ & $\begin{array}{r}8,488.6 \\
994.3 \\
746.4 \\
6,747.9\end{array}$ \\
\hline $\begin{array}{l}\text { Shelled corn, all treatments } \\
\text { Fumigation } \\
\text { Protectant } \\
\text { No treatment }\end{array}$ & $\begin{array}{r}558.3 \\
139.7 \\
70.4 \\
348.2\end{array}$ & $\begin{array}{r}359.7 \\
83.7 \\
35.0 \\
241.0\end{array}$ & $\begin{array}{r}318.1 \\
66.2 \\
29.8 \\
222.1\end{array}$ & $\begin{array}{r}182.5 \\
30.7 \\
13.9 \\
137.9\end{array}$ & $\begin{array}{r}68.3 \\
15.3 \\
5.2 \\
47.8\end{array}$ & $\begin{array}{r}1,486.9 \\
335.6 \\
154.3 \\
997.1\end{array}$ \\
\hline
\end{tabular}



